\title{
Agenda Open Government: Memerangi Korupsi Melalui Inisiatif Open Data
}

\section{AGIE NUGROHO SOEGIONO}

\section{Universitas Airlangga}

agienugroho@gmail.com

p-ISSN : 2477-118X

\section{A B S T R A K}

Esai ini mendiskusikan partisipasi masyarakat ataupun pemangku kepentingan nonpemerintah dalam upaya pemberantasan dan pencegahan korupsi di Indonesia. Mendeklarasikan diri sebagai salah satu pemerintah terbuka (Open Government) di dunia, Pemerintah Indonesia dalam beberapa tahun terakhir telah melakukan berbagai macam inisiatif keterbukaan guna merealisasikan peran riil masyarakat dalam mengawal pemerintahan yang transparan, akuntabel, responsif, dan bersih. Esai ini secara khusus mendiskusikan implementasi data terbuka (Open Data), salah satu inisiatif pemerintah untuk membuka informasi ataupun data pemerintah kepada publik sebagai kunci penting pencegahan dan pemberantasan korupsi. Selanjutnya, dalam esai ini dibahas dataset apa saja yang sekiranya harus dirilis oleh pemerintah, yang berpotensi untuk memaksimalkan penyelidikan kasus korupsi. Terakhir, esai ini memberikan empat rekomendasi yang ditujukan untuk perbai- 
kan tata kelola penyelenggaraan open data di Indonesia sebagai langkah nyata dalam memberantas korupsi.

Kata Kunci: Keterbukaan pemerintah, data terbuka, korupsi, KPK.

\section{A B S TRACT}

This essay discuses to what extent public or non-government actors could participate in corruption eradication and prevention. After declaring an as open government country, Indonesia has recently given tremendous efforts to encourage its people having their say in implementing transparent, accountable, responsive, and clean government. This essay specifically highlights the implementation of open data, one of the government's efforts to publish government data and information as an essential core to prevent and eradicate corruption acts. Further, the discussion depicts what kinds of datasets that should be provided to assist corruption investigation. Lastly, this essay provides four recommendations that suggest some improvements on open data management in Indonesia.

Keywords: Open government, open data, corruption, KPK.

\section{PENDAHULUAN}

Tragedi penyiraman air keras yang menimpa penyidik Komisi Pemberantasan Korupsi (KPK) Novel Baswedan baru-baru ini, kembali membuka mata publik akan risiko-risiko yang dihadapi dalam memerangi korupsi. Tindakan penganiayaan secara sengaja tersebut sontak menerima berbagai respons dari masyarakat. Najwa Shihab misalnya, salah satu reporter kenamaan Indonesia ini pun langsung menjadikan teror tersebut sebagai topik bahasan utama di acara talkshow-nya yang bertajuk "Kita KPK, KPK adalah kita". Memaknai judul tersebut, semangat yang diusung tentu bertujuan untuk meningkatkan kesadaran dan peran aktif masyarakat dalam upaya pencegahan dan pemberantasan korupsi. Namun, benarkah 
selama ini masyarakat memiliki peran signifikan dalam pemberantasan dan pencegahan korupsi? Apa yang bisa diperbuat masyarakat secara riil untuk membantu KPK menunaikan tugasnya? Agaknya pertanyaan-pertanyaan ini masih sulit dijawab.

Peran dan partisipasi publik dalam isu pembangunan dan kebijakan publik merupakan topik yang tidak pernah habis dibahas. Berbagai upaya telah dilakukan baik dari pemerintah maupun pemangku kepentingan lain untuk terus mengembangkan model pembuatan kebijakan dan pelaksanaan pembangunan yang demokratis, transparan, serta partisipatif. Platform yang memungkinkan terjadinya interaksi antara pemerintah dengan masyarakat terus bermunculan, sebut saja, Layanan Aspirasi Pengaduan Online Rakyat (LAPOR) yang diinisiasi Kantor Staf Presiden (KSP), aplikasi Clue yang menjadi ruh Jakarta Smart City, command-center milik Pemerintah Kota Surabaya, hingga ruang diskusi publik mingguan yang menjadi inisiatif Pemerintah Kabupaten Bojonegoro. Upaya-upaya tersebut merupakan contoh penerapan pemerintahan terbuka (Open Government) dalam memberikan kesempatan seluas-luasnya bagi masyarakat untuk aktif berpartisipasi dalam pembangunan dan peningkatan kualitas layanan publik. Partisipasi publik yang dimaksud juga termasuk hak untuk mengadu atau melaporkan suatu pelanggaran/penyelewengan lainnya kepada pemerintah dan aparat penegak hukum, salah satunya tindakan korupsi.

Sayangnya, dalam hal pemberantasan dan pencegahan korupsi, sejumlah platform yang ada selama ini belum signifikan. Partisipasi publik dinilai masih minim kontribusi dan pasif. Kalaupun ada, bentuk partisipasi masyarakat secara garis besar masih dalam tahap edukatif (Kurniawan 2009; Setiawan \& Pinatih 2013). Singkatnya, partisipasi masyarakat masih dinilai powerless. Alih-alih untuk ikut membantu pemberantasan korupsi, akses data dan informasi untuk mengidentifikasi tindakan korupsi saja masih sangat terbatas. Padahal, data dan informasi merupakan instrumen penting bagi masyarakat untuk turut serta mendeteksi tindakan penyelewengan.

Beberapa faktor berikut mengungkapkan penyebab partisipasi masyarakat masih dapat dikatakan minim dan lemah, terutama 
dalam mendapatkan akses data dan informasi terkait tindakan korupsi. Pertama, pemerintah masih bersikap reaktif daripada proaktif dalam memberikan data dan informasi yang relevan sebagai rujukan untuk penyelidikan korupsi. Kedua, keterbukaan akses publik terhadap data dan informasi pemerintah masih belum diperhitungkan secara signifikan kontribusinya dalam memerangi korupsi. Ketiga, kemampuan literasi data maupun pengelolaan informasi masyarakat untuk memerangi korupsi yang belum merata. Keempat, pemerintah sendiri masih belum secara jelas mendefinisikan perbedaan data dan informasi. Padahal, keduanya merupakan dua hal yang berbeda secara bentuk, ruang lingkup, dan kegunaannya. Kalau sudah begitu, mungkin saja "Kita KPK" selama ini hanya menjadi slogan belaka. Tetapi, bagaimana seandainya masyarakat diberikan akses kepada bahan-bahan rujukan yang bisa dianalisis untuk mengungkap suatu kasus tindakan korupsi? Bagaimana seandainya pemerintah menerapkan mekanisme proaktif dalam mempublikasikan data dan informasi seluas-luasnya secara otomatis, dalam format yang berkualitas, periodik, interoperabel, dan juga gratis?

Artikel ini berargumen bahwa pemberantasan dan pencegahan korupsi di Indonesia akan semakin efektif apabila masyarakat memiliki akses terhadap dataset pemerintah yang mampu membantu pendeteksian potensi tindakan korupsi. Dengan dibukanya dataset pemerintah yang menunjang pencegahan dan pemberantasan korupsi serta dibarengi masyarakat yang 'melek' data, barulah semua orang bisa 'menjadi KPK'. Dengan akses dataset yang bisa dijangkau oleh masyarakat, barulah mereka dapat turut aktif dalam membantu misi memerangi korupsi. Memahami dari segi pemerintah sendiri, masih banyak berbagai asumsi yang beredar bahwa merilis data dan informasi pemerintah malahan akan membahayakan status quo institusi pemerintah itu sendiri. Padahal, keterbukaan pemerintah sangat banyak manfaat dan potensinya untuk pembangunan. Premis dalam tulisan ini beranggapan "Kalau jujur dan bersih = berani terbuka dan rilis data". Kalau pemerintah bersih, dinamis, inovatif, dan partisipatif, pastilah tidak perlu takut untuk terbuka kepada publik. 
Sebaliknya, bila pemerintah takut, alergi, bahkan defensif terhadap keterbukaan, bisa jadi memang terdapat 'alasan' di belakangnya.

Struktur pembahasan dalam artikel ini dimulai dari diskusi terkait dengan upaya pemberantasan dan pencegahan korupsi di Indonesia saat ini. Sampai sejauh manakah upaya Indonesia dalam mencegah mengurangi tindakan korupsi? Upaya apa saja yang telah dilakukan KPK maupun pemangku kepentingan lain untuk mencapai hal tersebut? Halangan, tantangan, dan pembelajaran apa yang dapat kita pelajari selama ini? Kondisi teraktual terkait perilaku dan tindakan korupsi di Indonesia kemudian dilanjutkan dengan gambaran agenda nasional pemerintah Indonesia menuju pemerintahan terbuka. Dalam pembahasan tersebut, dijelaskan secara singkat namun rinci terkait urgensi pemerintah dalam menerapkan agenda keterbukaan seperti merilis data dan informasi yang diamanatkan oleh UU Keterbukaan Informasi Publik (KIP) tahun 2008.

Salah satu bentuk nyata pemerintah dalam penyelenggaraan keterbukaan saat ini adalah inisiatif data terbuka (Open Data Initiative), atau yang lebih dikenal di Indonesia dengan sebutan program Satu Data Indonesia (SDI). Open data tidak hanya sebatas diseminasi data pemerintah kepada publik. Namun, open data yang memiliki sifat interoperabel dengan aksesibilitas yang tinggi dan mudah akan membantu pemerintah dalam memadukan perencanaan, pelaksanaan, pemantauan, evaluasi, serta pengendalian pembangunan di tingkat pusat maupun daerah. Selain itu, dengan tersedianya data pemerintah untuk publik yang mudah didapat, gratis, dan dimutakhirkan secara periodik akan menguatkan partisipasi masyarakat untuk mengawal penyelenggaraan pemerintahan.

Singkatnya, program Satu Data Indonesia tidak hanya dapat menjadi solusi dalam memberikan data berkualitas bagi publik, namun juga menyelesaikan permasalahan data-data pemerintah yang selama ini masih berbeda-beda, terpisah-pisah, maupun diciptakan dan didistribusikan dalam format yang tidak terstandardisasi. Data dengan kualitas yang buruk akan mengakibatkan kualitas kebijakan yang tidak tepat sasaran. Kebijakan yang tidak tepat sasaran sangat 
berpotensi memicu kesempatan praktik-praktik tindakan korupsi di dalam implementasinya.

Di pembahasan terakhir, akan didiskusikan secara lebih rinci dan spesifik bagaimana open data dapat meningkatkan peran masyarakat untuk membantu pembangunan dan memerangi korupsi. Pemanfaatan data oleh masyarakat tidak hanya memperkuat pengawasan penggunaan anggaran pemerintah lebih komperehensif, namun juga akan secara otomatis meningkatkan kualitas pelayanan publik. Di sesi tersebut juga akan dibahas secara lebih rinci terkait dataset apa saja yang diperlukan dan berpotensi untuk digunakan dalam memerangi korupsi. Selama ini, open data belum menjadi prioritas mayoritas pemerintah dunia dalam menentukan strategi dalam memberantas dan mencegah korupsi (Rajshree \& Srivasta 2012: 21). Harapannya, artikel ilmiah ini akan menambah khazanah pengetahuan terkait upaya-upaya dalam memerangi korupsi. Terakhir, artikel ini akan memberikan rekomendasi strategis yang dapat diambil pemerintah terkait inisiatif open data dalam memerangi korupsi.

\section{Korupsi di Indonesia Hari Ini}

Pencegahan dan pemberantasan korupsi di Indonesia masih jauh dari kata selesai. Subbab berikut akan memaparkan beberapa data dari sejumlah riset terdahulu terkait perkembangan upaya pencegahan dan pemberantasan korupsi di Tanah Air.

Walaupun mengalami kenaikan peringkat secara signifikan dari peringkat 107 di tahun 2015 ke peringkat 88 di tahun 2016, Indonesia hanya mengalami sedikit improvisasi di penilaian Corruption Perception Index (CPI) dari 34 poin di tahun 2015 menuju 36 poin pada 2016 (Transparency Internaitonal Indonesia 2017: 12). Skor CPI berada pada rentang 0-100. Poin 0 berarti negara dipersepsikan sangat korup, sedangkan poin 100 dipersepsikan sangat bersih. Walau mengalami kenaikan sedikit dari tahun 2015 ke 2016, Indonesia secara konsisten mengalami tren kenaikan sejak 2012. Walaupun begitu, target pemerintah Indonesia sendiri yang berusaha mencapai skor CPI 50 poin belumlah tercapai. 
Temuan menarik lainnya diperoleh dari Global Corruption Barometer, sebuah riset yang memotret perkembangan pencegahan dan pemberantasan korupsi menurut persepsi masyarakat. Pada tahun 2013, jumlah persentase masyarakat yang menilai kinerja pemerintah dalam memberantas korupsi sudah efektif hanyalah sebesar 16\%. Secara mengejutkan, angka ini meningkat drastis di 2017 dimana keefektifan kinerja pemerintah dinilai meningkat oleh $64 \%$ dari jumlah responden. Sebanyak 78\% masyarakatpun setuju bahwa keterlibatan mereka sebagai penduduk sipil berperan besar dalam suksesnya dalam upaya pencegahan dan pemberantasan korupsi. Bentuk partisipasi masyarakatpun dilakukan dengan berbagai cara, baik yang bersifat reaktif ataupun proaktif. Namun, apabila dicermati, tingkat persentase partisipasi masyarakat secara proaktif seperti melaporkan korupsi, memilih kandidat politik bersih, berbicara dan menulis di media masih tergolong rendah (lihat Gambar 1).

Gambar 1: Bentuk Partisipasi Masyarakat dalam Melawan Korupsi di Indonesia

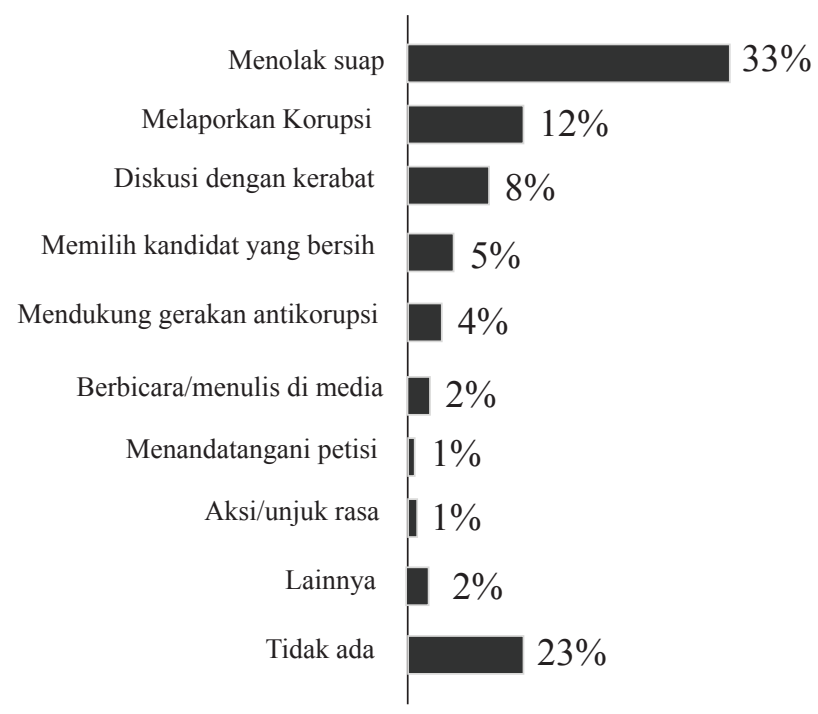

Sumber: ti.or.id 
Bahkan, sebanyak 23\% masyarakat memilih pasif dengan tidak melakukan apa-apa. Menurut indeks yang sama, pasifnya masyarakat disebabkan oleh ketidaktahuan menganai cara mekanisme dan tempat mereka harus melapor, yang jumlahnya mencapai $28 \%$ dari total responden. Hal ini menunjukkan bahwa partisipasi dan keterlibatan masyarakat dalam mencegah dan memberantas korupsi belumlah dapat dikatakan maksimal.

Menurut Transparency International Indonesia (2015), selama ini upaya pemberantasan dan pencegahan korupsi Indonesia masih terfokus pada upaya reformasi birokrasi atau perbaikan internal pemerintah. Memang birokrasi merupakan salah satu sektor dengan tindakan korupsi tertinggi. Namun, secara kuantitas sektor lain seperti korupsi politik, korupsi hukum, dan korupsi bisnis belumlah tersentuh secara signifikan.

Di level pemerintahan daerah, riwayat yang ditunjukkan oleh KPK mengindikasikan kebijakan desentralisasi atau otonomi daerah, kian berpotensi menjadi lubuk sasaran koruptor. Berdasarkan data yang dirilis dalam Laporan Tahunan KPK tahun 2016, tercatat dari 2004 hingga 2016, terdapat 124 anggota DPR/DPRD, $117 \mathrm{gu}-$ bernur dan 58 walikota/bupati/wakilnya yang ditangkap atas tuduhan tindakan korupsi. Di tahun 2016 sendiri, birokrat di tingkat pemerintahan daerah tercatat sebagai sektor terbanyak yang tersangkut kasus korupsi.

Berbicara mengenai kerugian negara dari temuan-temuan tersebut, hasil data Indonesia Corruption Watch (ICW) menunjukkan bahwa di tahun 2015 saja tindakan korupsi diperkirakan telah menyebabkan kerugian negara sebesar Rp.3,1 triliun. Tentu hal ini harus dibayar mahal masyarakat yang menjadi korban penyelewengan tersebut. Pembangunan menjadi tidak berjalan sebagaimana mestinya. Bagi masyarakat miskin, seringkali mendapatkan 'getahnya' yang dapat dilihat dari banyaknya warga miskin yang tidak mendapatkan akses bantuan sosial, pendidikan, dan kesehatan. Pergerakan ekonomipun secara otomatis juga menjadi tersendat karena perilaku korupsi. 
Kembali pada upaya penanganan korupsi, salah satu upaya untuk mengidentifikasi tindakan korupsi adalah dengan meningkatkan unsur transparansi kepada publik, termasuk perilisan data kepada publik. Open Data Barometer (ODB - opendatabarometer.org), sebuah inisiatif global untuk melihat perkembangan keterbukaan, menilai Indonesia belumlah cukup serius untuk mengimplementasikan keterbukaan data pemerintah kepada publik. Tercatat, dari 92 negara di dunia, Indonesia menempati urutan ke-40. Walau berada di posisi tengah, kesiapan Indonesia dalam melaksanakan keterbukaan data pemerintah hanyalah dinilai $46 \%$ dari kondisi standar ODB. Pemanfaatan keterbukaan datapun barulah mencapai 14\%. Hal ini tentu mengindikasikan pentingnya masyarakat Indonesia untuk lebih mengimprovisasi agenda keterbukaan pemerintahannya demi mewujudkan pembangunan yang bersih, jujur, akuntabel, efisien, efektif, dan tepercaya melalui pemanfaatan akses data. Subbab berikut akan membahas perjalanan panjang pemerintah Indonesia yang telah bertransformasi dari yang awalnya bersifat otoriter hingga lahirnya inisiatif untuk mengimplementasikan agenda open government.

\section{Kilas Balik Open Government Indonesia}

Kebijakan untuk merilis data pemerintah untuk publik di Indonesia merupakan sebuah perjalanan panjang yang dimulai dari runtuhnya otoritarianisme, meningkatnya peran media, hingga lahirnya landasan hukum terkait keterbukaan informasi publik.

Setelah runtuhnya rezim Orde Baru, tuntutan akan reformasi pemerintahan dalam hal transparansi, efisiensi kinerja pemerintah, pemberantasan korupsi, serta perbaikan birokrasi semakin kuat. Masyarakat yang dibungkam dan dikontrol secara politik maupun ekonomi di era Orde Baru, kini mulai bebas menyampaikan pendapat serta dilindungi aspirasinya. Diawali oleh UU Kebebasan Pers No. 40/ 1999, pemerintah tidak lagi kebal terhadap kritik. Suara masyarakat pada era reformasi kerap disampaikan dan disalurkan melalui berbagai model platform media. Pers yang awalnya dikekang 
kebebasannya oleh pemerintah, akhirnya dijamin kemerdekaan dan haknya dalam mencari, memperoleh, dan menyebarluaskan gagasan serta informasi. Pihak yang diberitakan pun juga dijamin oleh UU untuk memberikan hak jawab. Hal tersebut tentu berpengaruh secara signifikan dalam memantau kinerja pemerintah. Bisa dikatakan bahwa awal tercetusnya pemerintahan terbuka di Indonesia diawali di era reformasi dimana azas-azas demokrasi bangkit menyusul jatuhnya rezim Order Baru setelah tiga dekade memerintah dengan otoriter.

Azas demokrasi semakin berkembang setelah pemerintah mengesahkan UU Otonomi Daerah. Mengingat luasnya wilayah dan kompleksnya keberagaman pembangunan di Indonesia, pemerintah yang sentralistis dianggap tidak mampu untuk mengatur segala kebutuhan pembangunan, terlebih dalam memenuhi kebutuhan masyarakat di daerah (Lane 2014). Alhasil, pemerintah pusat kemudian membagi kewenangannya kepada daerah yang memungkinkan pemerintah daerah mempunyai peran lebih dalam jalannya pembangunan di areanya masing-masing. Selain lebih leluasa dalam mengatur dan mengelola potensi sumber daya di daerahnya masing-masing, pimpinan pemerintah daerah secara demokratis dipilih langsung oleh rakyat. Dinamika politik baru ini memungkinkan pengurangan eksklusivitas dalam tubuh pemerintahan yang selama ini didominasi oleh elite-elite politik tertentu. Namun, beberapa ilmuwan mengkritisi UU Otonomi Daerah justru melahirkan penguasa-penguasa baru di tingkat regional pula (lihat Mietzner 2015). Maka, diperlukan landasan hukum yang kuat dalam menelaah cross and balance kinerja pemerintah di semua tingkat. Tentu saja, untuk merealisasi hal tersebut dibutuhkan peran dan partisipasi masyarakat nonpemerintah yang harus dibekali informasi maupun data dalam mengawal kinerja pemerintahannya masing-masing.

Berdasarkan pertimbangan tersebut, akhirnya pada tahun 2008, Pemerintah Indonesia mengesahkan UU No. 14 tentang Keterbukaan Informasi Publik (KIP). Dengan diberlakukannya UU KIP, seharusnya pemerintah di semua level menjadi semakin transparan 
dalam membuka data dan juga informasi terkait pembangunan. UU KIP mengubah kondisi mekanisme keterbukaan informasi yang tadinya berupa close by default menjadi open by default. Artinya, secara otomatis, pemerintah memiliki kewajiban serta tuntutan untuk memublikasikan perkembangan terkini tentang pembangunan kepada masyarakat luas.

Pemublikasian informasi publik sendiri dilakukan melalui berbagai platform. Di daerah yang sudah dibekali teknologi dan sumber daya manusia (SDM), proses pemublikasian informasi dilakukan melalui website ataupun melalui portal berita khusus. Sedangkan di daerah yang belum maju secara teknologi, hal tersebut cukup dilakukan secara konvensional seperti melalui papan pengumuman yang dapat dilihat dan dibaca oleh masyarakat setempat ataupun melalui musyawarah rutin yang mempertemukan warga dan pejabat pemerintah lokal. UU KIP juga mengatur akses informasi secara kelembagaan. Salah satunya ketetapan untuk menunjuk Pejabat Pengelola Informasi dan Dokumentasi (PPID) dan Komisi Informasi. Hal ini bertujuan untuk memudahkan masyarakat dalam mengajukan permohonan data dan informasi kepada badan publik maupun mengajukan sengketa informasi publik. Dalam UU KIP, hak masyarakat untuk mendapatkan akses serta mengajukan gugatan terkait sengketa informasi dilindungi secara hukum demi menciptakan pemerintahan yang transparan, akuntabel, dan bersih. Jadi, UU KIP mengatur dan memfasilitasi pemublikasian data maupun informasi terkait pembangunan di setiap level pemerintahan terlepas keberagaman kapabilitas di masing-masing daerah.

Namun, implementasi hukum yang memungkinkan upaya transparansi pemerintah kepada publik tidak berjalan semulus yang direncanakan. Maka dari itu, pada tahun 2011, pemerintah Indonesia bersama tujuh pimpinan negara lainnya berinisiatif untuk membentuk suatu gerakan global yang membantu mempromosikan komitmen keterbukaan pemerintah di dunia yang bernama Open Government Partnership (OGP). Di sinilah perjalanan pemerintah Indonesia untuk menjadi pemerintahan yang terbuka berkembang 
dan terus melahirkan inovasi-inovasi untuk meningkatkan transparansi, partisipasi, dan kolaboratif publik.

Berdasarkan latar belakang di atas pertanyaan dari artikel ini adalah, "Bagaimana inisiatif open data dapat meningkatkan kualitas upaya pencegahan dan pemberantasan korupsi di Indonesia?" Pertanyaan ini akan dijawab melalui studi literatur tentang implementasi penyelenggaraan open government dan open data di berbagai belahan dunia.

\section{TINJAUAN TEORITIS}

Dalam sesi sebelumnya telah disinggung bahwa untuk menciptakan suatu iklim open government, pemerintah Indonesia merasa perlu untuk berpartisipasi dalam gerakan global. Open Government Partnership atau OGP merupakan bentuk komitmen global yang diinisiasi oleh 8 negara inisiator termasuk Indonesia di tahun 2011. OGP tidak hanya bertujuan untuk menekankan urgensi inisiatif open government di berbagai belahan dunia. Namun, OGP juga dapat menjadi suatu wadah pembelajaran bagi para pemimpin dunia untuk mempelajari praktik terbaik (best practices) inovasi keterbukaan di berbagai negara untuk dapat diterapkan di negaranya masing-masing. Secara khusus, bentuk konkret komitmen pemerintah Indonesia dalam merealisasikan agenda open government adalah dengan membentuk sekretariat Open Government Indonesia (OGI). Secara kepengurusan, OGI tidak hanya disupervisi lembaga pemerintah, seperti Bappenas dan Kantor Staf Presiden (KSP), namun juga secara langsung dikawal oleh beberapa lembaga nonpemerintah. Tercatat, saat ini ada 10 organisasi nonpemerintah yang terdaftar dalam kepengurusan OGI.

Namun, apa sebenarnya yang dimaksud dengan open government itu sendiri? Tinjauan teoritis berikut akan menjelaskan secara singkat konsep dan pemahaman dalam open government berikut dengan rencana pemerintah Indonesia terkini. 


\section{Apa dan Mengapa Open Government}

Gambar 2: Manfaat Inisiatif Open Government

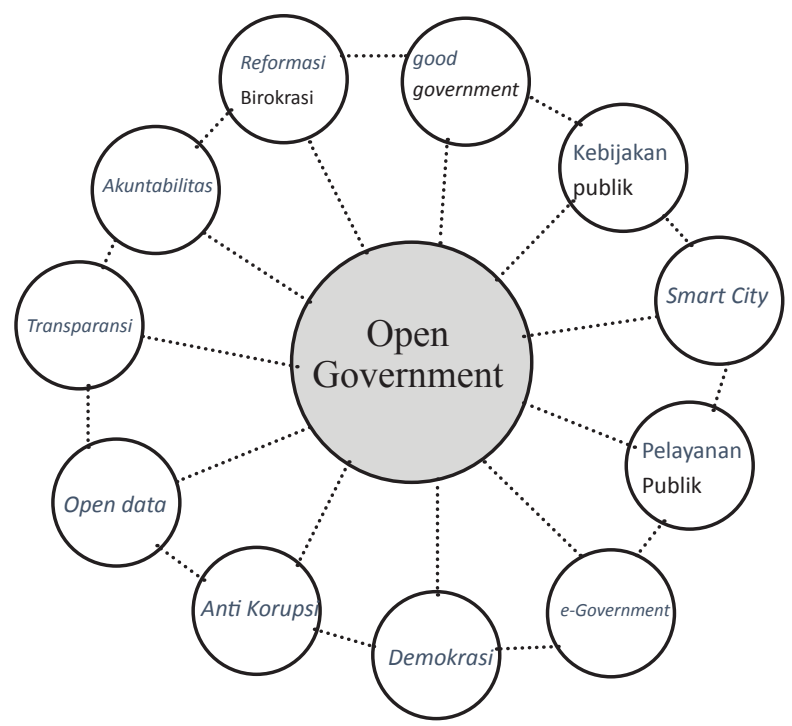

Sumber: opengovindonesia.org (2017)

Open Government menjadi sebuah istilah (term) yang digunakan di dunia internasional dalam mendorong upaya untuk meningkatkan kualitas keterbukaan pemerintah dan pelayanan publik. Menurut Harisson, et al (2012), open government dilandasi beberapa prinsip, seperti transparansi, partisipasi, dan kolaborasi. Dengan membuka dan memperluas akses informasi tentang pemerintah (termasuk di dalamnya mengurangi berbagai proses birokratis dalam mengaskses informasi), pemerintah akan secara otomatis dituntut untuk semakin meningkatkan kualitas layanan publik juga kualitas informasi itu sendiri. Kinerja pemerintah dan informasi yang buruk, tentu akan semakin mendapatkan tekanan secara politis dari masyarakat luas. Sebaliknya, pemerintah yang transparan dan terus berhasil mengimprovisasi layanan publik juga kualitas informasinya, akan semakin mendapatkan kepercayaan yang tinggi dari masyarakat. Hal terse- 
but, akan menstimulus dan menciptakan lingkungan partisipasi keterbukaan yang lebih meluas. Pada akhirnya, partisipasi yang meluas berpotensi untuk mendorong dan menguatkan peran masyarakat dalam pembangunan, baik dari peneliti, sektor privat, maupun organisasi masyarakat untuk berkolaborasi bersama dengan pemerintah (lihat Gambar 2).

Beberapa ilmuwan kerap berargumen bahwa open government sangat terbuka terhadap perkembangan teknologi (McDermott 2010; Harrison et al 2012; Rajshree \& Srivasta 2012). Teknologi informasi dan komunikasi (TIK) dianggap krusial dalam mereduksi, tidak hanya struktur birokrasi pemerintah yang berbelit-belit, namun juga meningkatkan efisiensi, efektivitas, juga kemudahan layanan publik itu sendiri. Layanan yang efisien, secara otomatis juga akan semakin mengurangi biaya prosedural yang kerap memboroskan anggaran pemerintah (Janssen et al: 2012). Berbeda halnya dengan layanan publik yang telah tersedia dalam format elektronik. Format " $e$ " atau electronic memungkinkan pemerintah dan masyarakat untuk lebih mudah dalam menganalisis perkembangan pembangunan yang telah atau sedang berjalan, termasuk di antaranya mendeteksi kemungkinan adanya tindakan korupsi. Meski begitu, penerapan open government di suatu daerah bukan berarti harus memiliki penguasaan TIK tingkat tinggi terlebih dahulu (Yu \& Robinson 2012: 181). Dengan kata lain, dalam memulai insiatif open government, penguasaan TIK bukanlah syarat mutlak.

Untuk memulai inisiatif open government, yang pertama kali diperlukan adalah komitmen high-level terkait transparansi informasi yang dihasilkan suatu institusi dan kemudian memublikasikannya kepada publik. Pemublikasian tersebut tidak selalu harus dilakukan melalui TIK yang canggih ataupun mutakhir. Sebuah riset yang dilakukan oleh Pawelke dan Canares (2016:15) menunjukkan, keterbukaan data fiskal yang dikeluarkan pemerintah daerah di pedalaman Yogyakarta dalam format konvensionalpun mampu menstimulasi proses peningkatan kesadaran dan partisipasi masyarakat terkait pengawasan anggaran. Riset tersebut juga menunjukkan bahwa per- 
an organisasi nonpemerintah juga memegang peran penting dalam membentuk ekosistem keterbukaan pemerintahan dengan memfasilitasi peningkatan literasi data maupun informasi masyarakat lokal. Dengan adanya masyarakat yang berdaya dan 'melek' informasi, tuntutan mereka terhadap penggunaan anggaran daerah agar dimanfaatkan seefisien dan seefektif mungkinpun, semakin meningkat.

Fokus open government tidak terbatas pada bagaimana pemerintah dapat mengimprovisasi tata kelola keterbukaan informasi publik-nya saja. Belakangan, agenda bahasan OGP berfokus pada kolaborasi pihak pemerintah dengan nonpemerintah melalui proses yang demokratis, akuntabel, dan transparan. Untuk mencapai hal tersebut, OGI (2016) sebagai gerakan pemerintahan terbuka nasional merilis rencana aksi tahunan yang bisa dilihat pada bagan berikut:

Gambar 3: Sinergi Rencana Aksi OGI dengan Rencana Pembangunan di Indonesia.

\begin{tabular}{|c|c|c|}
\hline \multicolumn{3}{|c|}{$\begin{array}{l}\text { Menghadirkan pemerintah dan membangun tata kelola yang bersih, efektif, demokratis, dan terpecaya } 5 \\
\text { Agenda Besar Pembangunan Nasional }\end{array}$} \\
\hline \multirow{3}{*}{$\begin{array}{l}\text { 1. Melanjutkan konsolidasi } \\
\text { demokrasi untuk memulihkan } \\
\text { kepercayaan publik; } \\
\text { 2. Meningkatkan peranan } \\
\text { dan keterwakilan perempuan } \\
\text { dalam politik dan } \\
\text { pembangunan; } \\
\text { 3. Membangun transparansi } \\
\text { dan akuntabilitas kinerja } \\
\text { pemerintahan; } \\
\text { 4. Menyempurnakan dan } \\
\text { meningkatkan kualitas } \\
\text { reformasi birokrasi nasional; } \\
\text { 5. Meningkatkan partisipasi } \\
\text { publik dalam proses } \\
\text { pengambilan kebijakan. }\end{array}$} & \multicolumn{2}{|c|}{$\begin{array}{l}\text { RPJMN 2015-2019 dalam membangun transparansi dan akuntabilitas } \\
\text { kinerja pemerintahan }\end{array}$} \\
\hline & \multirow[b]{2}{*}{$\begin{array}{l}\text { i. Penyempurnaan sistem } \\
\text { manajemen dan pelaporan } \\
\text { kinerja; } \\
\text { ii. Penerapan e-government } \\
\text { untuk mendukung bisnis } \\
\text { proses pemerintahan dan } \\
\text { pembangunan; dan } \\
\text { iii. Melalui penerapan open } \\
\text { government. }\end{array}$} & $\begin{array}{l}\text { Renaksi Open Government dalam } \\
\text { mengakselerasi komitmen pemer- } \\
\text { intahan terbuka }\end{array}$ \\
\hline & & $\begin{array}{l}\text { i. Peningkatan partisipasi } \\
\text { publik di dalam } \\
\text { penyelenggaraan pemerintah; } \\
\text { ii. Perbaikan tata kelola } \\
\text { pemerintahan melalui } \\
\text { penyempurnaan reformasi } \\
\text { birokrasi dan pelayanan publik; } \\
\text { iii. Penguatan keterbukaan } \\
\text { informasi publik; dan } \\
\text { iv. Penguatan tata kelola data. }\end{array}$ \\
\hline
\end{tabular}

Berdasarkan bagan di atas, dapat dilihat bahwa renaksi OGI didesain untuk menyesuaikan arah pembangunan nasional. Dalam merealisasikannya, open government membutuhkan hampir seluruh pemangku kepentingan yang tidak hanya 
dari sektor publik, namun juga beberapa sektor lain, baik yang terlibat langsung maupun tidak langsung dalam proses pembangunan. Menariknya, salah satu aspek vital dalam akselerasi open government di Indonesia adalah tata kelola data yang dipisahkan secara spesifik dengan tata kelola informasi yang ada di poin iii. Pada bagian berikut akan dibahas lebih rinci alasan pengelolaan data (dalam konteks ini, open data) secara khusus dipisahkan dengan informasi dan diatur untuk menunjang pembangunan di Indonesia.

\section{Open Data (Data Terbuka)}

Open data merupakan sebuah langkah lebih maju dalam implementasi keterbukaan informasi publik yang mengoptimalkan teknologi informasi dan komunikasi. Memasuki era digital dan internet dimana kebutuhan informasi semakin inklusif, open data menawarkan level keterbukaan lebih dalam yang menekankan diseminasi raw material (bahan mentah) dari sebuah informasi. Menurut Stagars (2016: 1) konsep open dalam open data menawarkan tidak hanya ketersediaan data secara daring (online availability), namun juga aksesibilitas bagi pengguna untuk menggunakan, membagikan, menganalisis ataupun mendistribusikan kembali data tersebut secara gratis. Lebih lanjut, Stagars membedakan open data dengan data publik dimana open data memiliki open license (lisensi terbuka) yang memungkinkan sebuah data digunakan untuk kepentingan komersial ataupun nonkomersial oleh siapapun. Walaupun begitu, open license dalam open data mengharuskan pengguna data untuk memberikan atribusi kepada lembaga/organisasi/perorangan yang telah memproduksi data tersebut (Creative Common by Attribution).

Kemampuan open data untuk diakses, diunduh, dan dibagi-pakaikan secara mudah disebut interoperabilitas. Karena kemampuan data yang interoperabel, open data dipercaya berpotensi untuk dimanfaatkan semaksimal mungkin untuk meningkatkan perekonomian, membantu efektivitas dan efisiensi kegiatan administrasi, me- 
ningkatkan kualitas transparansi dan akuntabilitas, dan menambah frekuensi partisipasi masyarakat dalam pembangunan. Open data normalnya dirilis dalam format yang terbuka pula. Format terbuka berarti kemampuan data untuk diakses menggunakan oleh perangkat lunak (software) apapun. Tim Berners Lee (dalam James: 2015), seorang ahli komputer kenamaan dunia, mengklasifikasikan open data menjadi lima tingkatan dimana ia merekomendasikan pemerintah, minimal mampu memublikasikan data dengan kemampuan level tiga atau data dengan format csv yang memiliki kemampuan machine readability yang bagus.

Gambar 4: Piramida DIKW oleh Adler dan Kitchin

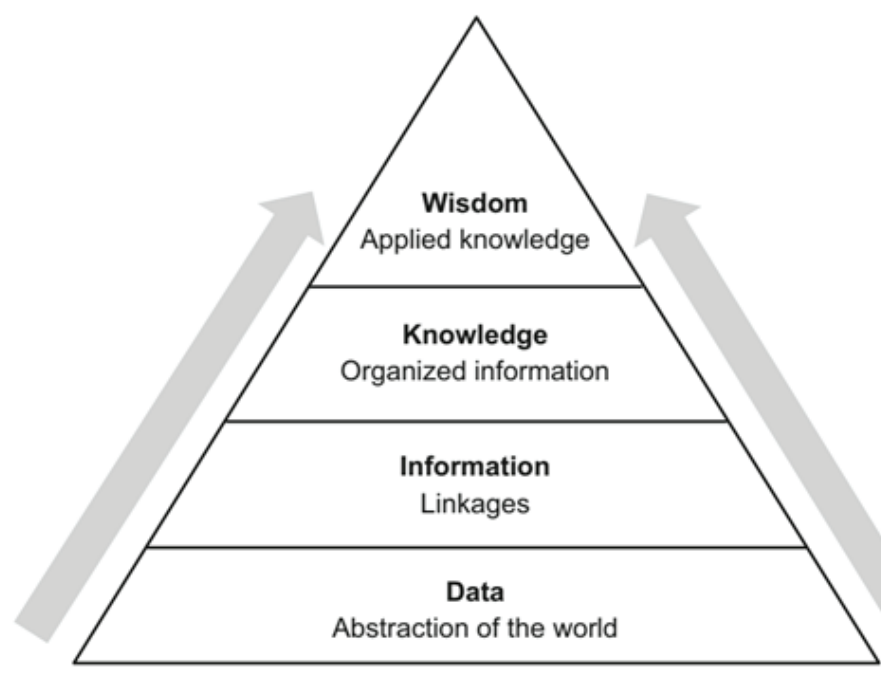

Data dipercaya sebagai unsur paling dasar yang harus diketahui dalam proses penemuan, penciptaan, dan pengaplikasian suatu pengetahuan (knowledge) untuk menjawab permasalahan-permasalahan publik. Oleh Adler dan Kitchin (dalam Stagars: 2016) data diilustrasikan dalam the knowledge pyramid data information knowledge and wisdom (DIKW) (lihat gambar 4). Data merupakan sebuah abstraksi dunia dimana individu/kelompok membutuhkan ketersediaan dan akses suatu data tersebut untuk dimanfaatkan lebih jauh. Dari data, akan lahir berbagai temuan informasi yang saling 
terhubung. Dari situ, para pengguna data dapat menerjemahkan informasi yang menjadi sebuah pengetahuan. Terakhir, pengetahuan dapat diaplikasikan dalam kehidupan sehingga mampu menjawab permasalahan-permasalahan yang tengah dihadapi manusia yang memetik kebijaksanaan dari pengalamannya.

\section{1. Open data di Indonesia - Program Satu Data Indonesia}

Komitmen penyelenggaraan open data sebagai prioritas pembangunan nasional kerap diawali dan tergantung oleh inisiatif elite politik. Misalnya, Inggris pertama kali mengawali komitmennya di tahun 2009. Ketika itu, jajaran pemerintah yang didominasi oleh koalisi Partai Buruh (Labour Party) merilis portal data.gov.uk, sebuah one-stop-searching portal data pemerintah (Transparency International UK: 2015). Kini, masyarakat Inggris tidak harus bingung dan menjalani proses yang panjang untuk mencari data pemerintah. Dengan adanya portal data yang terintegrasi dengan hampir seluruh departemen di Inggris, kini masyarakat maupun internal pemerintah dapat berbagi pakai data dengan mudah. Pengawasan terhadap pembangunanpun juga dapat dilakukan secara masif.

Belajar dari Inggris, di tahun 2014, Unit Kerja Presiden Bidang Pengawasan dan Pengendalian Pembangunan (UKP4) bersama dengan Badan Perencanaan Pembangunan Nasional (Bappenas), Badan Pusat Statistik (BPS), dan Badan Informasi Geospasial (BIG) merilis portal open data serupa yang dinamakan portal Satu Data Indonesia (www.data.go.id). Adapun penamaan Satu Data Indonesia (SDI) bertujuan tidak hanya untuk menambah kualitas keterbukaan dan kemampuan interoperabilitas data, namun SDI juga hadir untuk membantu keterpaduan perencanaan, pelaksanaan, pemantauan, evaluasi, serta pengendalian pembangunan antara pemerintah pusat dengan daerah yang selama ini kerap mendapati permasalahan perbedaan data yang tidak sama dan terintegrasi. Karena sifatnya yang hanya mengakomodasi data dan informasi secara digital, SDI merupakan bentuk akselerasi penerapan Sistem Pemerintahan Berbasis Elektronik (SPBE/ e-government) yang kini menjadi pembahasan 
di tingkat pusat. Menanggapi kondisi data yang dirilis oleh UKP4 di atas, Satu Data Indonesia rencananya akan diimplementasikan melalui tiga prinsip (OGI 2017), yaitu:

1. Satu standar data baku; satu standar yang mengatur metodologi yang meliputi konsep, definisi, cakupan, klasifikasi, ukuran, satuan dan asumsi.

2. Satu metadata baku; satu informasi tentang data (metadata) yang berfungsi untuk menjelaskan isi dan sumber data sehingga dapat mudah untuk ditemukan, digunakan, atau dikelola kembali.

3. Interoperabilitas data; kemampuan data untuk dipertukarkan atau dibagi-pakaikan antarsistem yang saling berinteraksi.

Berdasarkan tiga prinsip di atas, maka bukan tidak mungkin sistem pengelolaan data di Indonesia akan semakin berkembang dan lebih akuntabel, akurat, terintegrasi, termutakhirkan, dan yang paling penting, terbuka untuk seluruh lapisan masyarakat. Sayangnya, hingga tulisan ini selesai dibuat, Satu Data belum memiliki landasan hukum walau sudah berusia tiga tahun sejak peluncuran pertamanya. Sejauh ini, baru terdapat tujuh kementerian dan lima pemerintah daerah di seluruh Indonesia yang terhubung dalam sistem ini. Singkatnya, agenda open data di Indonesia bukan hanya sekadar meningkatkan kualitas data pemerintah untuk publik, namun juga agenda untuk menyatukan dan mengintegrasikan data pemerintah dalam program yang disebut dengan Satu Data Indonesia.

\section{2. Satu Data Indonesia dan UU Keterbukaan Informasi Publik.}

Dalam bagian sebelumnya disebutkan bahwa UU KIP merupakan landasan hukum yang memungkinkan diimplementasikannya agenda open government. Perubahan mekanisme pemublikasian informasi pemerintah dari yang awalnya close by default menjadi open by default, ternyata belum cukup untuk meng-cover rencana pelaksanaan open data. Salah satu faktor utamanya 
adalah kurang signifikannya pembahasan terkait data dalam UU KIP sendiri. Memang UU KIP telah memberikan peran besar dalam mendorong transparansi kinerja pemerintah dan menuntut pemublikasian segala informasi publik terkait pembangunan agar dapat diakses oleh masyarakat luas. Namun, dalam pengaturannya, UU KIP memiliki beberapa kelemahan, di antaranya:

1. Dalam UU KIP tidak disebutkan secara spesifik terkait pengelolaan tata kelola data. Yang ada barulah pengaturan pengelolaan informasi. Padahal, data dan informasi merupakan dua hal yang berbeda. Selama ini, data masih mengacu pada UU No. 16 tahun 1997 tentang statistik yang didefinisikan sebagai "Informasi yang berupa angka tentang karakteristik (ciri-ciri khusus) suatu populasi.” Definisi ini sudah dianggap tidak lagi relevan. Apalagi, bentuk data tidak hanya berupa data statistik saja.

2. Karena belum adanya pengaturan terkait pengelolaan data, perilisan datapun tidak terstandardisasi dengan baik. Alhasil, setiap kementerian, lembaga, dan pemerintah daerah di Indonesia merilis data sesuai dengan kewenangannya masing-masing. Akibatnya, sering terjadi kasus ditemukannya dua dataset yang sama, namun isinya berbeda. Padahal, perbedaan satu angka saja pada suatu dataset, akan sangat memungkinkan seseorang/kelompok untuk melakukan tindakan korupsi. Kesulitan dalam pengelolaan data yang berbeda-beda akhirnya berdampak pada pembangunan yang tidak akurat (misalnya, tidak semua sekolah mendapatkan bantuan Bantuan Operasional Sekolah (BOS) karena perbedaan data yang diterima di Kementerian Pendidikan dan Kebudayaan dengan Dinas Pendidikan dan Kebudayaan di daerah).

3. Banyak data yang dirilis tidak memiliki kemampuan interoperabilitas yang tinggi. Data kebanyakan sudah berformat .pdf (sudah menjadi data olahan atau informasi) atau sekadar dicantumkan pada website (lihat Gambar 3 sebelumnya). Data 
yang interoperabel memungkinkan antarinstansi pemerintah untuk membagi-pakaikan untuk diolah ataupun dianalisis kembali. Selain itu, data yang dikelola dalam sistem yang interoperabel memungkinkan penyederhanaan mekanisme birokratis yang memakan waktu dan biaya. Singkatnya, data dalam format standar open data yaitu csv masih belum banyak tersedia di Indonesia.

4. Proteksi terhadap data masih besar. Belum ada klasifikasi data atau data spectrum yang jelas dalam pengaturan KIP. Klasifikasi data berfungsi untuk mengidentifikasi mana data yang dapat dibagikan kepada publik maupun data yang hanya dibatasi aksesnya di kalangan internal pemerintah. Merilis data seringkali dianggap membahayakan bagi institusi tersebut. Akibatnya, pelayanan terhadap permohonan informasi menjadi rancu dan tidak ada standar yang jelas untuk menerima ataupun menolak permohonan data. Hal ini menunjukkan, permintaan data dan informasi oleh masyarakat kepada pemerintah, masih cenderung reaktif dan belum proaktif.

5. Beberapa data publik (atau setidaknya biaya yang diperlukan untuk mengurus permintaan informasi) belum sepenuhnya gratis. UU KIP memang melandasi layanan publik dalam mengurus permohonan suatu data ataupun informasi secara mudah dan dengan biaya yang murah. Namun, pada praktiknya, proses pengajuan peromohonan informasi tidak memakan biaya yang sedikit. Karena prosesnya yang masih konvensional, pengajuan informasi masih harus melalui alur-alur yang birokratis yang tidak hanya memakan waktu namun juga biaya yang dikeluarkan. Beberapa data yang diproduksi oleh BPS juga dipatok dengan harga yang tidak murah (UKP4, 2014). Selama ini, pemerintah masih belum menimbang valuasi suatu data apabila dirilis dalam format terbuka dan dapat dimanfaatkan oleh masyarakat banyak. BPS maupun badan lain yang melakukan produksi datapun masih menganggap data adalah suatu produk Penerimaan Negara Bukan Pajak (PNPB) yang 
dinilai potensial untuk menambah kas lembaga. Alhasil, masyarakat ataupun pemangku kepentingan yang ingin memanfaatkan data publik harus merogoh kocek yang tidak sedikit.

Berdasarkan rincian di atas, dapat disimpulkan urgensi implementasi open data haruslah segera diakomodasi oleh pemerintah agar tata kelola dan penyelenggaraan data dapat segera dilembagakan melalui landasan hukum yang jelas untuk implementasinya. Secara rinci, UKP4 (sekarang, Kantor Staf Presiden, 2014) menggambarkan permasalahan tata kelola data di Indonesia sebagai berikut:

Gambar 5: Pemetaan Kondisi Tata Kelolda Data di Indonesia

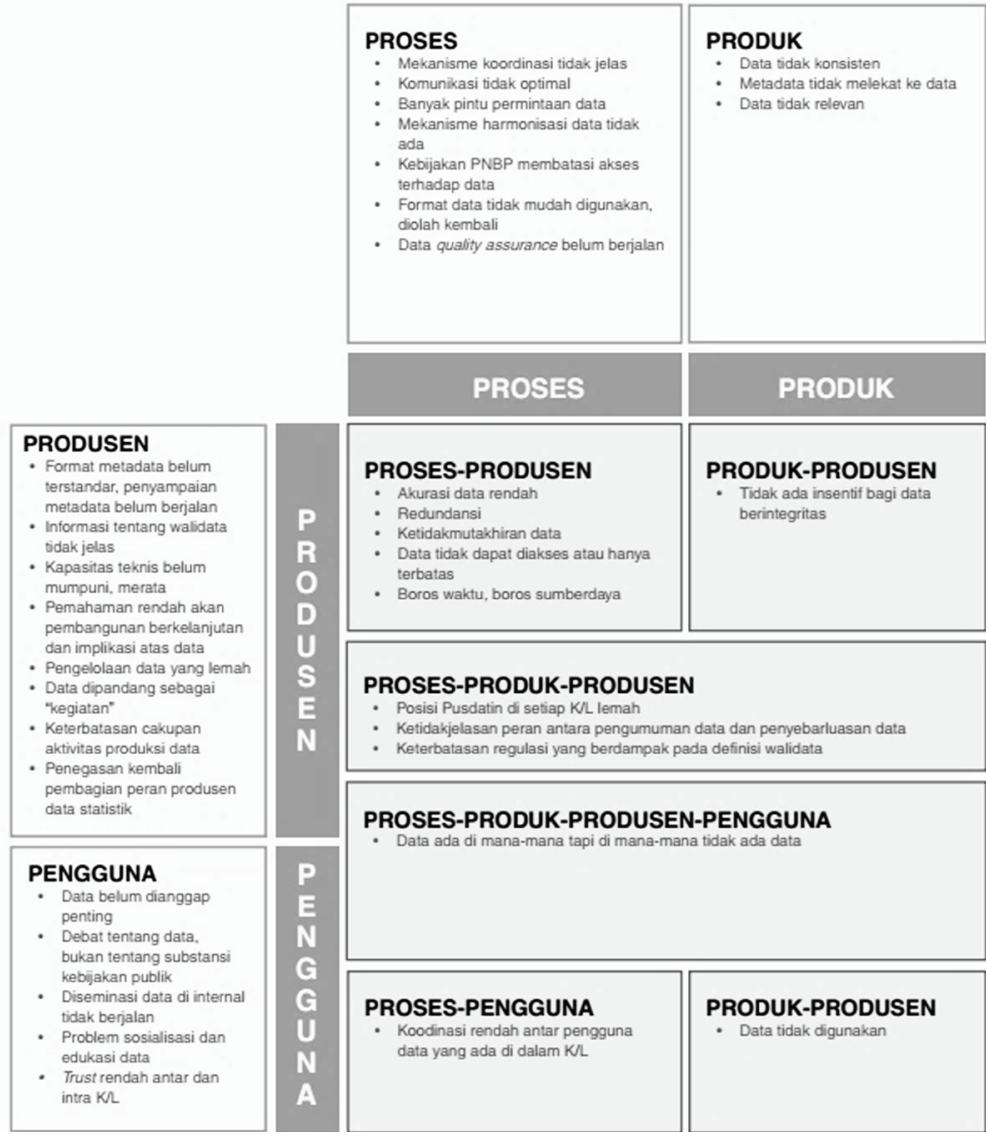

Sumber: Cetak Biru Satu Data (UKP4, 2014) 
"Data ada dimana-mana tapi dimana-mana tidak ada data", menjadi sebuah kalimat singkat yang menggambarkan sistem pengelolaan tata kelola dan penyelenggaraan data pemerintah di Indonesia. Hanya karena tidak bisa dengan mudah membagi-pakai data, pelayanan di institusi pemerintah menjadi tidak responsif, mahal, dan cenderung mudah diselewengkan. Perbedaan data bisa membuat implementasi pembangunan menjadi salah sasaran. Sebagai contoh, karut-marut dalam pengurusan asuransi Badan Penyelenggara Jaminan Sosial (BPJS) Kesehatan. Salah satu penyebab sulitnya administrasi dan penanganan orang sakit melalui BPJS adalah karena sulit serta minimnya data yang interoperabel yang bisa dengan mudah dibagi-pakaikan antara Dinas Kesehatan, Dinas Kependudukan, rumah sakit setempat, dan BPJS itu sendiri. Alhasil, pelayanan menjadi tidak maksimal dan kepercayaan masyarakat kepada pemerintah juga menurun. Lain halnya dengan layanan baru Jakarta Smart City, dengan sistem data yang interoperabel, pasien dapat mengetahui dimana rumah sakit dengan kamar kosong yang tersedia tanpa susah payah mengunjungi satu rumah sakit ke rumah sakit lainnya.

\section{PENYAJIAN DATA DAN PEMBAHASAN}

\section{Bagaimana Open Data Mengakselerasi Agenda Open Government}

Pembentukan ekosistem open government tidak memakan waktu yang sebentar. Beth Noveck (2012), mantan staf Presiden Obama yang menginisiasi pemerintahan terbuka Amerika Serikat, menuturkan bahwa ekosistem open government akan terbentuk dalam dua fase. Pertama adalah fase bagaimana pemerintah secara internal mampu melakukan harmonisasi, memperbaiki regulasi, maupun melakukan perbaikan sistem tata kelola data dan informasi untuk publik. Fase ini bertujuan untuk memproduksi data dan informasi yang berkualitas, serta bagaimana sistem pengelolaan antar subsistem pemerintah menjadi interoperabel untuk berbagai pakai data dan informasi secara cepat. Hal serupa juga diungkapkan oleh 
Layne dan Lee (2001:125), di fase satu seharusnya antardivisi ataupun departemen di dalam pemerintahan dapat saling melakukan cross-check terkait kinerja maupun anggaran pada masing-masing unit kerja. Alhasil, kebocoran atau penyelewengan anggaran yang berpotensi masuk dalam kategori korupsi dapat terdeteksi dengan lebih mudah. Karena interoperabilitas sangat mengedepankan pada penggunaan TIK, maka riwayat transaksi akan selalu terekam secara otomatis. Namun, dalam fase ini masyarakat masih belum sepenuhnya mampu mengelola ataupun menganalisis data maupun informasi yang dirilis oleh pemerintah.

Fase kedua adalah ekosistem pemerintahan terbuka yang bercirikan masyarakat yang tidak hanya 'melek data', namun juga mampu melakukan berbagai inovasi dari data yang dirilis. Open data memungkinkan pemerintah dan lembaga nonpemerintah untuk menganalisis pembangunan secara real-time. Bayangkan saja, data anggaran rumah sakit pemerintah yang dirilis secara terbuka dan periodik, akan memungkinkan tidak hanya pembuat kebijakan terbantu untuk menentukan arah perbaikan layanan kesehatan dengan lebih akurat, namun tingkat kepercayaan dan kepuasaan masyarakat juga akan semakin tinggi atas layanan yang diberikan. Karena sifatnya yang real-time dan mudah diakses oleh masyarakat luas, open data mampu menghilangkan stigma yang disematkan kepada institusi pemerintah dengan peningkatan aspek keadilan, stabilitas, dan efisiensi pelayanan publik. Dengan kata lain, open data hanya akan memberikan dampak positif pada pembangunan apabila data tersebut dapat dimanfaatkan. Inti dari fase kedua open government adalah bagaimana data dan informasi yang sudah dirilis dapat dimanfaatkan semaksimal mungkin dengan inovasi-inovasi yang diciptakan oleh masyarakat sudah 'melek' terhadap data dan informasi.

\section{Open Data Dapat Mengimprovisasi Pemberantasan dan Pencegahan Tindakan Korupsi}

Merujuk pertanyaan awal pada artikel ini, metode apa yang memungkinkan peningkatan kualitas keterlibatan masyarakat untuk 
pemberantasan dan pencegahan korupsi? Salah satunya adalah pemberian data dan informasi yang memadai terkait tindakan korupsi. Open data yang dirilis dalam format mentah memungkinkan setiap orang untuk menganalisis dan menyimpulkan informasi apa yang dapat diperoleh dari data tersebut (Yu \& Robinson 2012: 189). Berdasarkan temuan Yu dan Robinson, pemberantasan dan pencegahan korupsi dapat diperkuat melalui beberapa faktor, di antaranya penguatan hukum, peran investigasi awak media, keterbukaan informasi publik, dan laporan masyarakat (whistleblowing). Lantas hanya dua faktor terakhir yang memungkinkan masyarakat luas untuk berpartisipasi dalam memerangi korupsi, yaitu keterbukaan informasi publik dan laporan masyarakat.

Menurut riset yang dilakukan di Uni Eropa (Transparency International UK: 2015), kebijakan terkait open government data berpotensi untuk meningkatkan nilai perekonomian hingga $€ 200$ juta per tahun secara keseluruhan. Riset dari McKinsey juga mendukung hasil tersebut. Dalam laporannya (2013: 2), McKinsey \& Company mengestimasi valuasi keterbukaan data berpotensi untuk meningkatkan nilai ekonomi dunia hingga US\$ 3 triliun. Dari dua temuan tersebut, dapat dikatakan bahwa dengan merilis open data, pemerintahan beserta layanan publiknya akan menjadi semakin bersih, efisien, dan efektif. Dengan manfaat-manfaat tersebut, secara otomatis nilai ekonomi dari suatu negara dapat meningkat secara drastis.

Open data barulah awal dari sebuah proses dimana masyarakat luas akhirnya dapat mengakses dataset yang berpotensi untuk mencegah dan memberantas korupsi. Grafis berikut menerangkan bahwa semakin berkualitas keterbukaan open data pada sebuah negara, semakin positif indeks persepsi korupsi atau corruption perception index (CPI). Dari grafis statistik tersebut, dapat dianalisis bahwa semakin berkualitasnya data pemerintah yang dirilis ke publik, semakin meningkatkan pengawasan terhadap pembangunan di suatu negara tersebut (lihat figur 6). Contohnya Jerman yang memiliki indeks kesiapan open data sebesar 73\%, ternyata mendapatkan 
skor CPI yang cukup bagus yakni, 81 (semakin tinggi, semakin tidak korup negara tersebut). Negara lainnya yang memperoleh raihan cukup bagus di Open Data Barometer adalah Prancis. Dengan perolehan 80 poin dalam kesiapan penyelenggaraan open data-nya, Prancis memperoleh hasil yang cukup bagus pula pada indeks persepsi korupsi sebesar 70. Sebaliknya, Indonesia yang hanya memiliki indeks kesiapan open data sebesar 46\%, hanya meraih CPI sebesar 36 . Tentu, ini mengindikasikan bahwa Indonesia harus segera berbenah terutama dalam penyelenggaraan tata kelola data. Penyelenggaraan tata kelola data harus segera diimprovisasi demi meningkatkan kualitas pemberantasan dan pencegahan korupsi. Penjelasan lebih detail terkait ketersediaan data pada ketiga negara tersebut akan dibahas di subbab berikut.

Gambar 6: Korelasi Positif Open Data Barometer dengan Corruption Perception Index

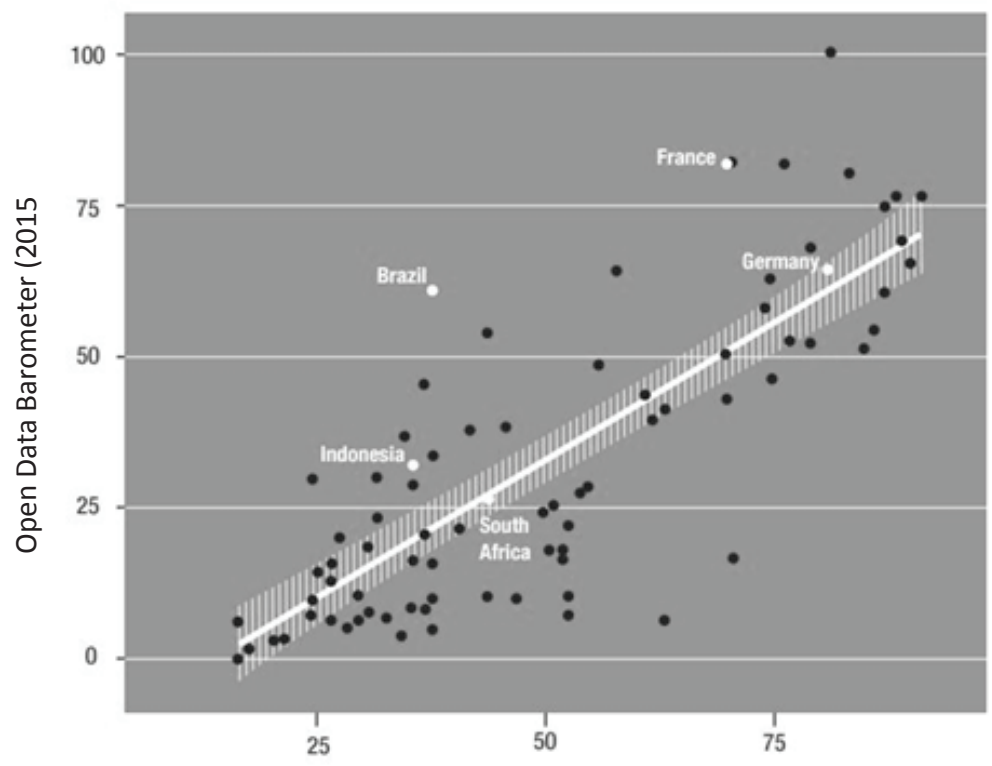

Corruption Perceptions Index (2015)

Sumber: Open Government Indonesia (opengovindonesia.org) (2017) 


\section{Penyelenggaraan Open Data untuk Melawan Korupsi - Sebuah Perbandingan}

Keberhasilan beberapa negara dalam menerapkan pemerintahan bebas dari korupsi tidak terlepas dari komitmen negara tersebut untuk menyelenggaraan keterbukaan informasi dan data kepada publik. Melanjutkan paparan pencapaian open data barometer dan juga corruption perception index di atas, subbab berikut mencoba untuk mendalami ketersediaan dan kualitas open data dari dua aspek, yaitu ketersediaan open data dan kualitas open data. Adapun negara yang dimaksud adalah Indonesia, Prancis, dan juga Jerman.

Sebuah riset yang dikeluarkan oleh Transparency International pada 2017 merekomendasikan 10 dataset dan 9 aspek kualitas open data terkait analisis tindakan korupsi. Adapun 10 dataset yang direkomendasikan untuk dipublikasikan adalah: registrasi para lobbyist, registrasi perusahaan, aset berupa informasi terkait pemilik modal, fungsi direktorat aparatur sipil negara, anggaran APBN secara detail, pembelanjaan negara secara detail, riwayat lelang untuk publik, keuangan untuk pencalonan pemilihan politik, hasil voting para wakil rakyat, dan juga registrasi tanah.

Selain rekomendasi 10 dataset untuk dibuka kepada publik, Transparency International juga merekomendasikan 9 aspek penting untuk diterapkan guna meningkatkan kualitas data tersebut, yakni mekanisme pengunduhan online, pembagian data berdasarkan periodik, granularitas data, format data, transparansi data (openness), aksesibilitas, kesamaan standar keterbukaan dengan data yang lain, metadata, dan yang terakhir dokumentasi. Kedua unsur ketersediaan dan kualitas data tersebut menjadi ukuran yang digunakan dalam penilaian Open Data Barometer.

Menurut Transparency International, ketersediaan open data di Indonesia masih sangat terbatas (lihat figur 6). Dari 10 ketersediaan dataset yang direkomendasikan Transparency International untuk pencegahan dan pemberantasan korupsi, dataset yang sudah terbuka barulah registrasi perusahaan (company registers), APBN (government budget), dan juga lelang publik (public procurement). Dari 
terbatasnya ketiga dataset tersebut, kualitasnyapun masih juga diragukan. Data APBN misalnya, masih belum/tidak semuanya diseminasi dalam format terbuka (openness) yang bisa digunakan kembali, dibagi-pakaikan, dan machine-readible. Walaupun sudah tersedia, bisa jadi konten besaran APBN pemerintah yang dipublikasikan kepada masyarakat sudah dalam bentuk informasi tanpa adanya perilisan data $\mathrm{APBN}$ secara rigit.

Lain halnya dengan kondisi di Prancis dan Jerman. Ketersediaan jenis dataset di Prancis mencapai 8 dari 10 data yang direkomendasikan oleh Transparency International. Kualitas datanyapun juga bisa dibilang bagus. Dari 8 dataset yang tersedia, masing-masing jenis dataset setidaknya sudah memiliki minimal lima aspek kualitas data. Walaupun tidak memiliki ketersediaan data sebanyak Prancis, Jerman memiliki tujuh dari 10 jumlah ketersediaan dataset yang berpotensi untuk mencegah dan memberantas korupsi. Baik Prancis dan Jerman keduanya menunjukkan performa yang bagus dalam CPI dibandingkan Indonesia. Hal tersebut mengindikasikan krusialnya ketersediaan data publik pada penyelenggaraan pemerintahan yang akuntabel dan bebas dari korupsi.

\begin{tabular}{|c|c|c|c|c|c|c|c|c|c|c|}
\hline naceron & & & & & & & & 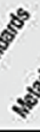 & & 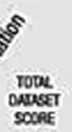 \\
\hline Lobbying registers & $x$ & $x$ & $x$ & $x$ & $x$ & $x$ & $x$ & $x$ & $x$ & 0 \\
\hline Company registers" & $\checkmark$ & $x$ & $x$ & $\checkmark$ & $x$ & $\checkmark$ & $\checkmark$ & $\checkmark$ & $x$ & 5 \\
\hline Beneficial ownership & $x$ & $x$ & $x$ & $x$ & $x$ & $x$ & $x$ & $x$ & $x$ & 0 \\
\hline Public officials & $x$ & $x$ & $x$ & $x$ & $x$ & $x$ & $x$ & $x$ & $x$ & 0 \\
\hline Government budget" & $\checkmark$ & $\checkmark$ & $\checkmark$ & $\checkmark$ & $x$ & $\checkmark$ & $\checkmark$ & $x$ & $\checkmark$ & 7 \\
\hline Government spending & $x$ & $x$ & $x$ & $x$ & $x$ & $x$ & $x$ & $x$ & $x$ & 0 \\
\hline Public procurement" & $\checkmark$ & $\checkmark$ & $x$ & $x$ & $x$ & $\checkmark$ & $x$ & $x$ & $x$ & 3 \\
\hline Political financing & $x$ & $x$ & $x$ & $x$ & $x$ & $x$ & $x$ & $x$ & $x$ & 0 \\
\hline Voting records & $x$ & $x$ & $x$ & $x$ & $x$ & $x$ & $x$ & $x$ & $x$ & 0 \\
\hline Land registers & $x$ & $x$ & $x$ & $x$ & $x$ & $x$ & $x$ & $x$ & $x$ & 0 \\
\hline
\end{tabular}

Indonesia 


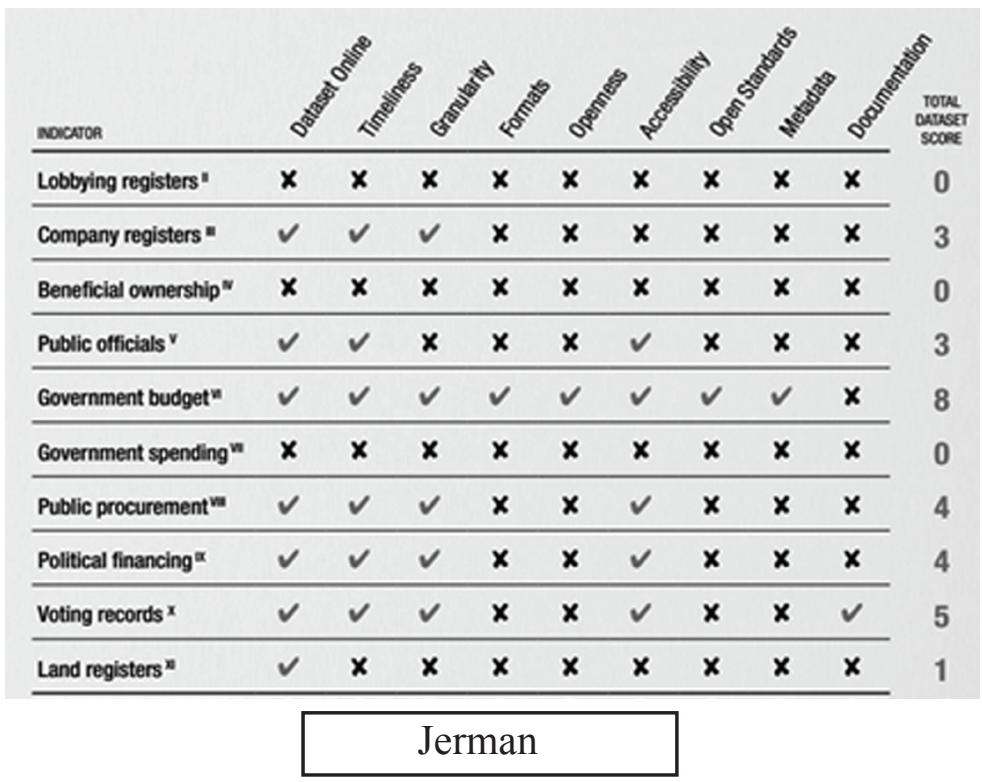

\begin{tabular}{|c|c|c|c|c|c|c|c|c|c|c|}
\hline nolceror & & & & & & & of & $\$$ & $0^{\circ}$ & 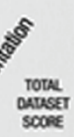 \\
\hline Lobbying registers " & $x$ & $x$ & $x$ & $x$ & $x$ & $x$ & $x$ & $x$ & $x$ & 0 \\
\hline Company registers " & $\checkmark$ & $\checkmark$ & $\checkmark$ & $x$ & $x$ & $x$ & $x$ & $x$ & $x$ & 3 \\
\hline Beneficial ownership" & $x$ & $x$ & $x$ & $x$ & $\mathbf{x}$ & $x$ & $\mathbf{x}$ & $x$ & $x$ & 0 \\
\hline Public officials ${ }^{\vee}$ & $\checkmark$ & $\checkmark$ & $x$ & $x$ & $x$ & $\checkmark$ & $x$ & $x$ & $x$ & 3 \\
\hline Government budget & $\checkmark$ & $\checkmark$ & $\checkmark$ & $\checkmark$ & $\checkmark$ & $\checkmark$ & $\checkmark$ & $\checkmark$ & $x$ & 8 \\
\hline Government spending"w & $x$ & $x$ & $x$ & $x$ & $x$ & $x$ & $x$ & $x$ & $x$ & 0 \\
\hline Public procurement ${ }^{\text {tw }}$ & $\checkmark$ & $\checkmark$ & $\checkmark$ & $x$ & $x$ & $\checkmark$ & $x$ & $x$ & $x$ & 4 \\
\hline Political financing $\alpha$ & $\checkmark$ & $\checkmark$ & $\checkmark$ & $x$ & $x$ & $\checkmark$ & $x$ & $x$ & $x$ & 4 \\
\hline Voting records $x$ & $\checkmark$ & $\checkmark$ & $\checkmark$ & $x$ & $x$ & $\checkmark$ & $x$ & $x$ & $\checkmark$ & 5 \\
\hline Land registers $x$ & $\checkmark$ & $x$ & $x$ & $x$ & $x$ & $x$ & $x$ & $x$ & $x$ & 1 \\
\hline
\end{tabular}

Gambar 7: Perbandingan ketersediaan dan kualitas dataset untuk pencegahan dan pemberantasan korupsi di tiga negara.

Sumber: Transparency International Indonesia, Transparency International France, Transparency International Germany (2017) 


\section{Tantangan Penyelenggaraan Open Data}

Open data barulah awal dari sebuah proses dimana masyarakat luas akhirnya dapat mengakses dataset yang berpotensi mencegah dan memberantas korupsi. Untuk dapat menganalisis, menarik kesimpulan, mendeteksi, dan/atau mengembangkan valuasi dataset tersebut, dibutuhkan upaya untuk meningkatkan literasi data masyarakat/organisasi nonpemerintah (lihat Pawelke \& Canares: 2016).

Berdasarkan hasil beberapa riset sebelumnya, ketersediaan open data masih belum dianggap genting bagi pemerintah dalam menelusuri tindakan korupsi. Kondisi pasif tersebut akhirnya kurang menstimulasi diangkatnya suatu perkara korupsi yang bisa diangkat oleh masyarakat. Salah satu penyebabnya adalah masih sedikitnya kesadaran pemerintah maupun masyarakat akan manfaat keterbukaan data publik. Alhasil, berdasarkan rilisan terbaru dari OGI, masih sangat sedikit sekali pemerintah daerah yang tergabung dalam inisiatif-inisiatif keterbukaan pemerintah seperti open data.

Bagi masyarakat sendiri, kesadaran akan hak untuk mengakses informasi yang dilindungi oleh landasan hukum juga relatif kecil (Siregar 2017). Selain masih cukup rendahnya masyarakat yang mendapatkan akses internet (22\%), tingkat kemampuan masyarakat dalam memahami data maupun informasi juga relatif rendah. Terlebih, pemerintah Indonesia masih belum memahami ataupun memiliki dataset yang mampu mendukung dalam memberantas dan mencegah korupsi.

\section{REKOMENDASI KEBIJAKAN}

Berdasarkan penjabaran di atas, tulisan ini bermaksud untuk memberikan rekomendasi kebijakan sebagai berikut:

1. Identifikasi dataset kunci untuk penyelidikan korupsi. Walau mendapatkan rekomendasi dataset dari Transparency International, pemerintah perlu mengupayakan dan menemukan 
jenis data apa saja yang diperlukan dan paling berpotensi dan sesuai dengan kondisi Tanah Air untuk meningkatkan kapabilitas institusi pemerintah maupun masyarakat dalam berpartisipasi memerangi korupsi. Dataset terkait korupsi tersebut akan menjadi kunci penting dalam memberantas ataupun mencegah korupsi yang terjadi, baik dalam pemerintah ataupun luar pemerintah.

2. Dataset kunci terkait korupsi haruslah dipublikasikan dalam format terbuka. inisiatif open data memerlukan bentuk pelayanan publik yang bersifat proaktif dan bukan reaktif. Oleh karena itu, diperlukan upaya untuk memperkuat kapabilitas instansi pemerintah yang bertanggung jawab melakukan tata kelola dan proses diseminasi data. Setelah itu, untuk dapat memaksimalkan open data, pemerintah harus menyediakan landasan hukum yang kuat bagi pemangku kepentingan, baik perseorangan maupun secara organisasi dalam mengakses ketersediaan data-data yang dirasa penting sebagai dasar bukti yang menunjukkan indikasi kuat penyelidikan tindakan korupsi. Dengan adanya landasan hukum yang kuat untuk mendukung sikap proaktif dalam menyelenggaraan open data, upaya pembarantasan dan pencegahan korupsi akan semakin menguat melalui proses legal dalam mengedukasi publik terkait kasus tindakan korupsi yang tengah diperkarakan.

3. Penerapan implementasi pilot project. Penerapan open data terkait tindakan korupsi perlu dilakukan di daerah percontohan terlebih dahulu. Hal ini akan bermanfaat sebelum melakukan proses negosiasi untuk meyakinkan pemerintah pusat ataupun yang berwenang untuk penerapan open data di skala yang lebih luas.

4. Pemberdayaan pengguna data seluas-luasnya. Pentingnya peran intermediaries sebagai mediator untuk meningkatkan kapabilitas stakeholder dalam memanfaatkan open data sebagai alat untuk mengungkap adanya potensi tindakan korupsi baik di internal pemerintah ataupun nonpemer- 
intah. Kualitas dalam memberantas korupsi akan menjadi semakin efektif apabila kedua sektor tersebut telah memiliki kapabilitas yang mumpuni dalam memanfaatkan data.

"KPK adalah Kita" seharusnya lebih dari sekadar slogan. Indonesia yang sudah bertahun-tahun dicap sebagai negara korup, perlahan tapi pasti mulai memperbaiki diri. Komitmen besar dari Pemerintah Indonesia dalam mengimplementasikan inisiatif keterbukaan pemerintah menjadi 'angin segar' bagi agenda pemberantasan korupsi di Indonesia. Sayangnya, mengubah kultur yang awalnya close by default menjadi open by default tidaklah semudah dan secepat itu. Perlu sebuah komitmen bersama yang perlu dibangun dan ditingkatkan antara pemerintah dan masyarakat. Melalui keterbukaan pemerintah dan open data, Indonesia diyakini telah memasuki sebuah fase baru untuk menjadi negara yang lebih dewasa dalam menegakkan nilai-nilai demokratis, partisipatif, dan kolaboratif. Open data diyakini akan menjadi kunci dalam mewujudkan hal tersebut. Dengan semua pemangku kepentingan dapat mengakses data maupun informasi dalam format yang terbuka, niscaya kualitas pembangunan maupun pelayanan publik akan semakin dapat terealisasi.

\section{REFERENSI}

Harrison et al. (2012). Open Government and E-Government: Democratic Challenges from a Public Value Perspective. IOS Press, Information Polity 17 (2012) 83-97

Indonesia Corruption Watch. (2016). Kerugian Negara Akibat Korupsi 2015 Sebesar 3,1 Triliun, tersedia di http://www. antikorupsi.org/id/content/kerugian-negara-akibat-korupsi2015-sebesar-31-triliun (diakses 16 April 2017)

James. (2015). $5 \star$ Open Data, tersedia di: http://5stardata.info/en/ (diakses: 19 April 2017)

Janssen et al. (2012). Benefits, Adoption Barriers and Myths of Open Data and Open Government. Information Systems Man- 
agement, 29:4, 258-268

Korupsi Pemberantasan Korupsi. (2016). Laporan Tahunan 2016 tersedia di https://www.kpk.go.id/images/Laporan\%20Tahunan\%20KPK\%202016\%20Bahasa\%20Indonesia.pdf (diakses 19 April 2017)

Kurniawan. (2012). Peranan Akuntabilitas Publik dan Partisipasi Masyarakat dalam Pemberantasan Korupsi di Pemerintahan, Bisnis \& Birokrasi. Jurnal Ilmu Administrasi dan Organisasi, Mei-Agustus 2009, hlm. 116-121

Lane. (2014). Decentralization \& Its Discontents: An Essay on Class, Political Agency and National Perspective in Indonesian Politics. ISEAS Publishing, Pasir Panjang, Singapore

Layne \& Lee. (2011). Developing Fully Functional E-government:

A Four Stage Model. Government Information Quarterly 18, hlm. 122-136

McKinsey\&Company. (2013). Open Data: Unlocking Innovation and Performance with Liquid Information tersedia di: http://www.mckinsey.com/ /media/McKinsey/Business\%20 Functions/McKinsey\%20Digital/Our\%20Insights/Open\%20 data $\% 20$ Unlocking\%20innovation $\% 20$ and $\% 20$ performance\%20with\%20liquid\%20information/MGI_Open_data_ Executive_summary_Oct_2013.ashx (diakses 18 April 2017) Mietzner. (2015). Jokowi's Challenge: The Structural Problems of Governance in Democratic Indonesia. Governance: An International Journal of Policy, Administration, and Institutions, Vol. 28, No. 1, January 2015 (hlm. 1-3)

Noveck, Beth. (2012). Demand a More Open-source Government, tersedia di https://www.ted.com/talks/beth_noveck_ demand_a_more_open_source_government (diakses 15 April 2017)

Open Data Barometer http://opendatabarometer.org.

Open Government Indonesia. (2016). Rencana Aksi Nasional Keterbukaan Pemerintah 2016-2017, tersedia di: http://www.opengovpartnership.org/sites/default/files/31102016_Renaksi\%20 
OGI\%202016-2017.pdf (diakses 15 April 2017).

Pawelke, \& Canares. (2016). Open data dan Keterbukaan Fiskal: Bagaimana Kita Dapat Memperoleh Manfaatnya? Pembelajaran dari Projek Percontohan di Indonesia dan Filipina, Open Data Labs Jakarta, tersedia di: http://labs.webfoundation.org/ wp-content/uploads/2016/02/OD4T-Lessons-Learned-IDScreen.pdf (diakses 11 April 2017)

Rajshree, \& Srivasta. (2012). Open Government Data for Tackling Corruption - A Perspective. Semantic Cities AAAI Technical Report WS-12-13

Setiawan \& Pinatih. (2013). Optimalisasi Peran Serta Masyarakat dalam Pemberantasan Tindak Pidana Korupsi, Kertha Wicara Vol. 01, No. 03, Juli 2013

Siregar et al. (2017). Complaining to Improve Governance: Four Stories of Complaint-handling Systems in Indonesia, Making All Voices Count Research Report, Brighton: IDS

Stagars, Manuel. (2016). Open Data in Southeast Asia: Towards Economic Prosperity, Government Transparency, and Citizen Participation in the ASEAN. Palgrave Pivot.

Transparency International France. (2017). Open Data Against Corruption in France, tersedia di: http://webfoundation.org/ docs/2017/04/2017_OpenDataFrance_EN-3.pdf (diakses 12 April 2017)

Transparency International Germany. (2017). Open Data Against Corruption in Germany, tersedia di: http://webfoundation.org/ docs/2017/04/2017_OpenDataGermany_EN-3.pdf (diakses 12 April 2017)

Transparency International Indonesia. (2017). Open Data Against Corruption in Indonesia,. tersedia di: http://webfoundation. org/docs/2017/04/2017_OpenDataIndonesia_EN-2.pdf (diakses 12 April 2017)

Transparency International UK. (2015). How Open Data Can Help Tackle Corruption, tersedia di: https://www.google.co.id/ webhp? sourceid $=$ chrome-instant\&ion $=1 \&$ espv $=2 \&$ ie $=U T F-$ 
$8 \# \mathrm{q}=$ how + open + data + can + tackle + corruption + uk + pdf $\quad($ diakses 10 April 2017)

Undang-Undang Republik Indonesia Nomor 14 Tahun 2008 Tentang Keterbukaan Informasi Publik.

UKP4 (Unit Kerja Bidang Pengawasan dan Pengendalian Pembangunan). (2014). Cetak Biru Satu Data untuk Pembangunan Berkelanjutan

Yu \& Robinson. (2012). The New Ambiguity of 'Open Government', 59 UCLA L. Rev. Disc. 178 (2012). tersedia di: https:// ssrn.com/abstract=2012489 or http://dx.doi.org/10.2139/ ssrn.2012489 (diakses 12 April 2017) 